\title{
BLAJ WHITE WINES CHARACTERIZATION
}

\author{
RAMONA BLEIZIFFER ${ }^{a}$, SONIA SUVAR ${ }^{a}$, PAULA PODEA $^{\text {b }}$, \\ CORNELIA MESAROS $^{\mathrm{c}}$, MONICA CULEA ${ }^{\mathrm{a}}$
}

\begin{abstract}
Six white wines from Blaj vineyard obtained from clone and new created varieties of grapes, have been studied. Their volatile compounds, free amino acids, free fatty acids, content in polyphenols and flavonoid, antioxidant and antityrosinasic activity were compared. The results showed few differences among the analyzed wines. The volatile extracts of wines gave very similar compounds. The major compounds were phenylethyl alcohol. All the white wines of Blaj contained a large amounts of proline in comparison with the other amino acids and important essential amino acids. The fatty acids were found in very small quantities. Antioxidant activity and total content in polyphenols of wines showed that Muscat Ottonel have a very high antioxidant potential comparable with some red wines. The content in flavonoids is small in all white wines. Antityrosinasic activity of studied wine proved to be high to Blasius and Muscat Ottonel wine. The GC-MS method proved to be an excelent method for wine characterization.
\end{abstract}

Keywords: essential amino acids, amino acids, fatty acids, antioxidant activity, GC/MS

\section{INTRODUCTION}

Wine is an important beverage and it is consumed by human for thousands of years. Obtained from grapes, wine has a multitude of beneficial effect due to the chemical composition very related with fruits and herbs.

${ }^{a}$ Babes-Bolyai University, Faculty of Physics, 1 Kogalniceanu st., Cluj-Napoca, Romania

${ }^{b}$ Babes-Bolyai University, Faculty of Chemistry and Chemical Engineering, 11 Arany Janos st., Cluj-Napoca, Romania,

*Corresponding author: mpaula@chem.ubbcluj.ro

${ }^{c}$ University of Medicine and Pharmacy, 38 Gh. Marinescu st., Târgu Mureş, Romania 
Romania has a tradition in wine production, being on $12^{\text {th }}$ place top of world wine production [1] and the sixth wine producer in the European Union. It is very important for appreciation the origin of wines, the consumers are using this attribute to evaluate the wine quality [2]. In Romania, there are some different recognized vineyards which offer high quality products. One of them is Tarnave-Jidvei Vineyard, which has four wineries: Jidvei, Blaj, Balcaciu and Tauni [3].

There are different elements which are influencing the composition, taste, aroma and properties of wines. Amino acids are importance to wine flavour and aroma because they constitute a source for yeast metabolism [4]. Most important are varieties of grapes, geographical origin, weather condition and human factor [5].

In literature, studies based on components characterization (phenolic compounds, amino acids, aroma compounds) are used for classification and comparison of wines [6-8].

The micronutrients in food are very important. Amino acids play an important role in human nutrition. In many foods, the level of essential amino acids dictates its nutritive value. Volatiles, amino acids, fatty acids influence wine taste. Antioxidant activity reflects the healthy value of wine.

Amino acids in wine have a considerable influence on wine quality and taste, being a source of nutrients for yeast fermentation [9].

Amino-acids profile in wine can be used to classify and differentiate wine on variety and geographical origin [5]. Volatiles profile in wines is connected with aroma, taste and varieties of wines [10]. The volatile composition depends also on the geographical origin, climate and viticulture proceeding, being an important indicator for wine characterization [11]. Fatty acids are minor components found in wines, but fatty acids composition can influence the wine aroma and taste [7]. Phenolic compounds are important constituents, natural antioxidants, found in wine, with a major influence in sensory assets, colour and taste [12]. Wine is a natural source of antioxidants and proves to have important healthy benefit in a balanced diet $[13,14]$.

The aim of our study was to compare and characterize six white wines produced in 2014, from grapes cultivated in Blaj Vineyard, Tarnave area, Transylvania. The wines are obtained from clone and new created varieties of grapes obtained at Research Station of Viticulture and Enology Blaj [15].

\section{RESULTS AND DISCUSSION}

Six white wines from Blaj vineyard (Fetească regală, Blasius, Neuburger, Traminer roz, Muscat Ottonel, Selena) have been studied. Their physical-chemical characteristics, volatile compounds, free amino acids, free 
fatty acids and content in polyphenols and flavonoid, antioxidant and antityrosinasic activity were compared.

Amino acids and fatty acids profiles were analyzed. The chemical composition of volatiles was determined and compared. Also, the content in polyphenols and flavonoid, antioxidant and antityrosinasic activity were compared.

Fatty acids were derivatized as fatty acid methyl esters (FAME) and in the case of amino acids as trifluoroacetic butyl esters derivatives to improve volatitity and for better separation. The content in amino acids is influenced mainly by varieties of grapes, geographical origin and fermentation condition.

The dominant amino acids identified in the wines were proline (15.7mg/ml in Blasius), glutamic acid, aspartic acid, gama-aminobutiric acid, alanine, glycine and lysine. Proline is the major amino acid in wine samples released in the fermentations and it is an intermediate product in the degradation of arginine [4]. The high concentrations of proline in wine is owed to the fact that yeast microorganisms do not consume this amino acid. Arginine was not found in wine because it is consumned during fermentation by yeast [16].

The total free amino acids were in the range $10.2 \mathrm{mg} / \mathrm{ml}$ (Feteasca Regala Blaj) and 19.2mg/ml (Traminer Roz Blaj). Essential amino acids (EAA) had value ranged from $0.45 \mathrm{mg} / \mathrm{ml}$ (Neuburger) to $1.44 \mathrm{mg} / \mathrm{ml}$ (Traminer Roz).

The fatty acids present in wines were lower than $20 \mu \mathrm{g} / \mathrm{ml}$, stearic acid, palmitic acid and linoleic acid being dominant.

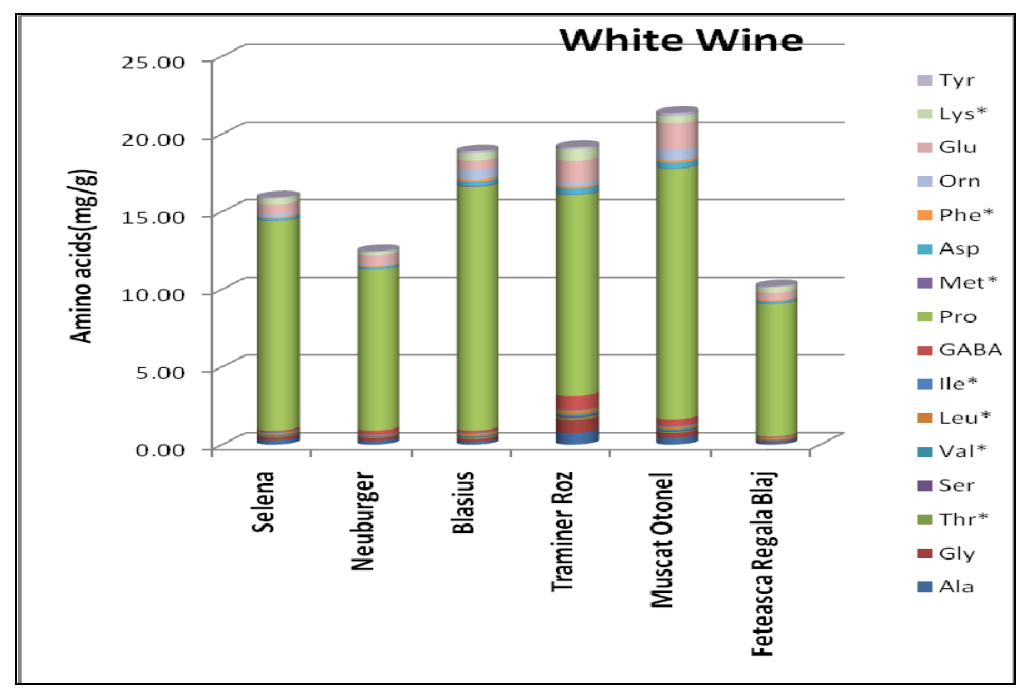

Figure 1. Free amino acids in Romanian wines 


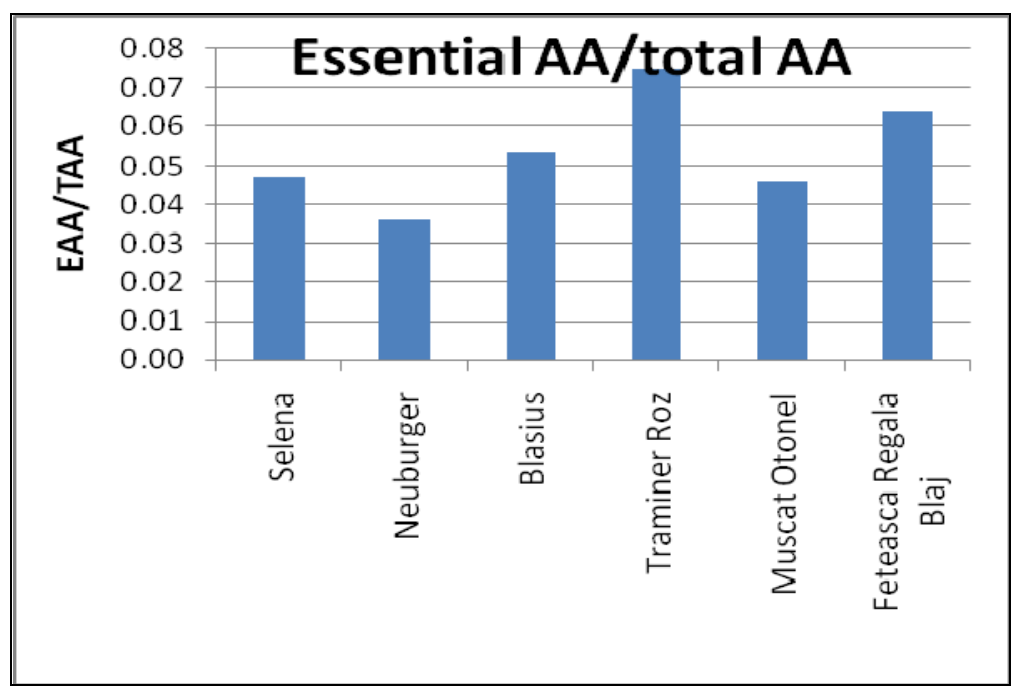

Figure 2. Ratio of essential amino acids and total amino acid

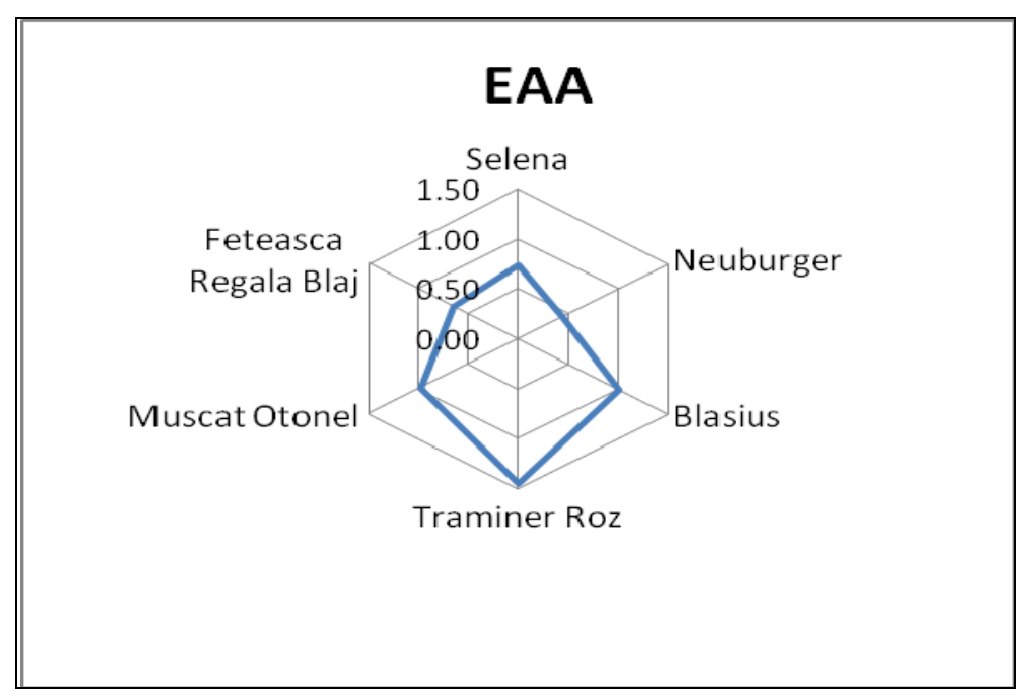

Figure 3. Comparison of essential amino acids $\left(\mathrm{mg} \cdot \mathrm{g}^{-1}\right)$

The volatile extracts of wines gave very similar compounds. The major compounds were phenylethyl alcohol (21.5\%-Muscat Otonel to $45.76 \%$-Neuburger), succinic acid monoethyl ester (17.29\%-Neuburger to $37.4 \%$-Blasius) and 4-hydroxy-phenylethanol (6.7\% in Muscat Otonel to $15.37 \%$ in Feteasca Regala. The high abundance of 2-phenylethanol was also detected in other wines. [11] 


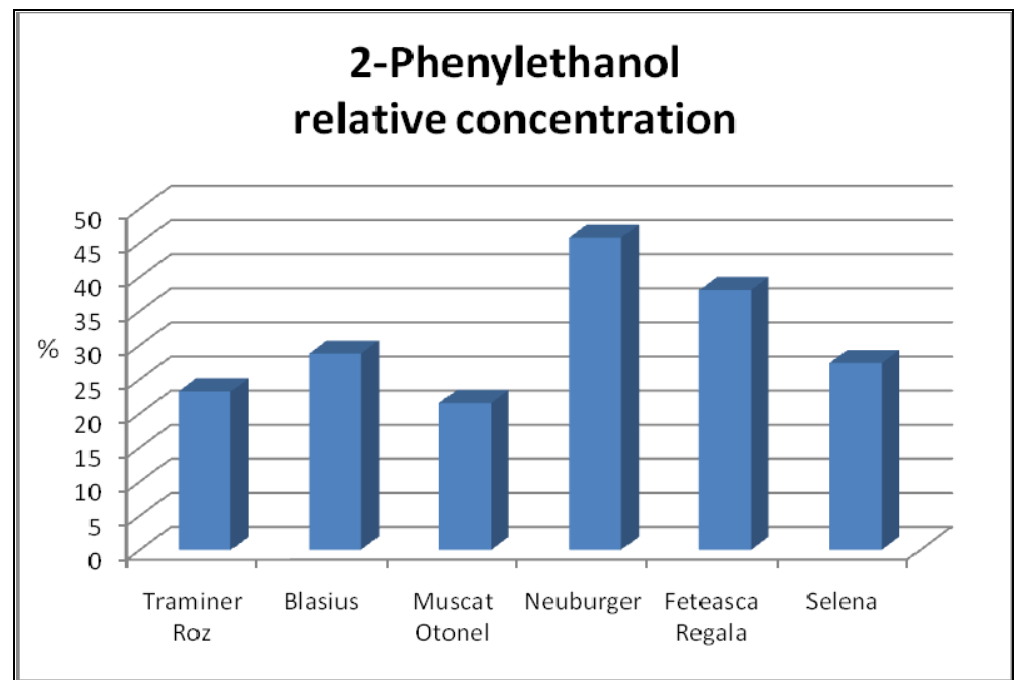

Figure 4. Relative concentration of phenethylalcohol in different wines from Blaj area

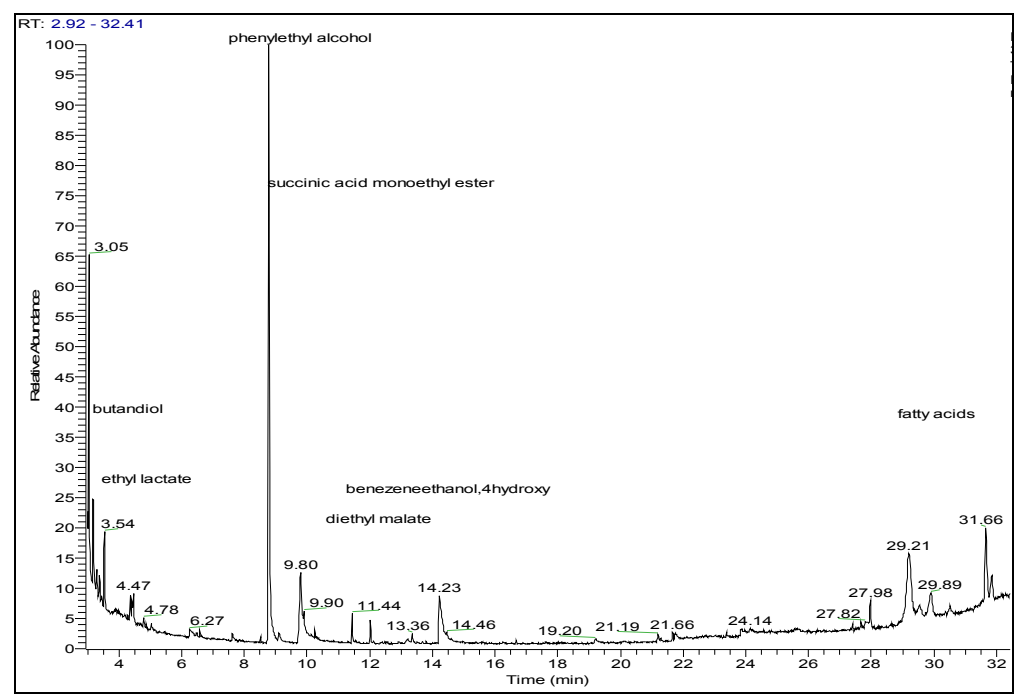

Figure 5. The GC chromatogram of volatiles identified in Neuburger wine

The antioxidant attributes of the selected wines were evaluated using DPPH (1,1-diphenyl-2-picrylhydrazyl), free radical scavenging antioxidant assays and TEAC (Trolox equivalent antioxidant capacity). Also the total polyphenolic content(TPC) and content of flavonoids were determined. 
White wines Muscat Ottonel and Feteasca Regala show a high antioxidant activity. A moderate antioxidant activity was observed in white wine Neuburger, Jidvei, Selena, Blasius. The antioxidant activity of wines was confirmed also by using TEAC assay. The content of polyphenols was indicated a higher quantity of polyphenols in Muscat Ottonel wine $(1310 \mathrm{mg}$ GAE/L), followed by Feteasca Regala wine (810 mg GAE/L), values comparable with the total polyphenols content in some red wines $[17,18]$, but lower than other red wines [19]. A lower quantity of polyphenols was found in Blasius wine, but comparable with some others Romanian white wines [20]. It is known that flavonoids are found in skin of grapes, are very healthier, but are causing a bitterness effect on wines [21]. That's why producers of white wines are not using the skin of grapes not to alter the wine taste. The flavonoid content in white wines is not as high as in red wines also due to originally low quantity of flavonoids found in white grapes. All white wines studied have a low quantity on flavonoids, the highest quantity was found in Selena wine $8.96 \mathrm{mgQuE} / \mathrm{L}$.

Table 1 Antioxidant capacity parameters obtained using several methods and total polyphenols content and total flavonoids content in studied wines. (Each value is the mean \pm SD of two independent measurements).

\begin{tabular}{|c|c|c|c|c|}
\hline Wine & $\begin{array}{c}\text { DPPH } \\
\text { decolorization }(\%) \\
(10 \mu \mathrm{g} / \mathrm{ml})\end{array}$ & $\begin{array}{c}\text { TEAC } \\
(\mathrm{mmolsTE} / \mathrm{ml} \\
\text { wine })\end{array}$ & $\begin{array}{c}\text { TPC } \\
(\mathrm{mg} \mathrm{GAE} / \mathrm{ml} \\
\text { wine })\end{array}$ & $\begin{array}{c}\text { Flavonoids } \\
(\mu \mathrm{gQuE} / \mathrm{ml} \\
\text { wine })\end{array}$ \\
\hline Blasius & $19.3 \pm 0.62$ & $4.97 \pm 0.01$ & $0.22 \pm 0.02$ & $7.21 \pm 0.14$ \\
\hline Selena & $22.5 \pm 0.45$ & $6.04 \pm 0.13$ & $0.29 \pm 0.01$ & $8.96 \pm 0.17$ \\
\hline Fetească regală & $35.9 \pm 0.81$ & $8.84 \pm 0.53$ & $0.81 \pm 0.03$ & $2.46 \pm 0.16$ \\
\hline Muscat Ottonel & $43.9 \pm 0.34$ & $9.72 \pm 0.17$ & $1.31 \pm 0.09$ & $3.75 \pm 0.03$ \\
\hline Neuburger & $30.4 \pm 0.58$ & $7.66 \pm 0.10$ & $0.64 \pm 0.03$ & $0.78 \pm 0.07$ \\
\hline Traminer roz & $24.5 \pm 0.72$ & $7.15 \pm 0.22$ & $0.31 \pm 0.01$ & $1.00 \pm 0.06$ \\
\hline
\end{tabular}

Tyrosinase is an important enzyme involved in melanin biosynthesis [22]. Extracts and compounds which show anti-tyrosinasic inhibitory activity are useful whitening agents in cosmetics or additives in food industry to prevent fruits enzymatic browning phenomenon [23].

Anti-tyrosinase inhibitory activity of studied wines was evaluated. All wine prove to have a slightly inhibitory activity on tyrosinase enzyme, but Blasius and Muscat Ottonel wine proved to have a good inhibitory activity, lowering the reaction rate with $75 \%$. 


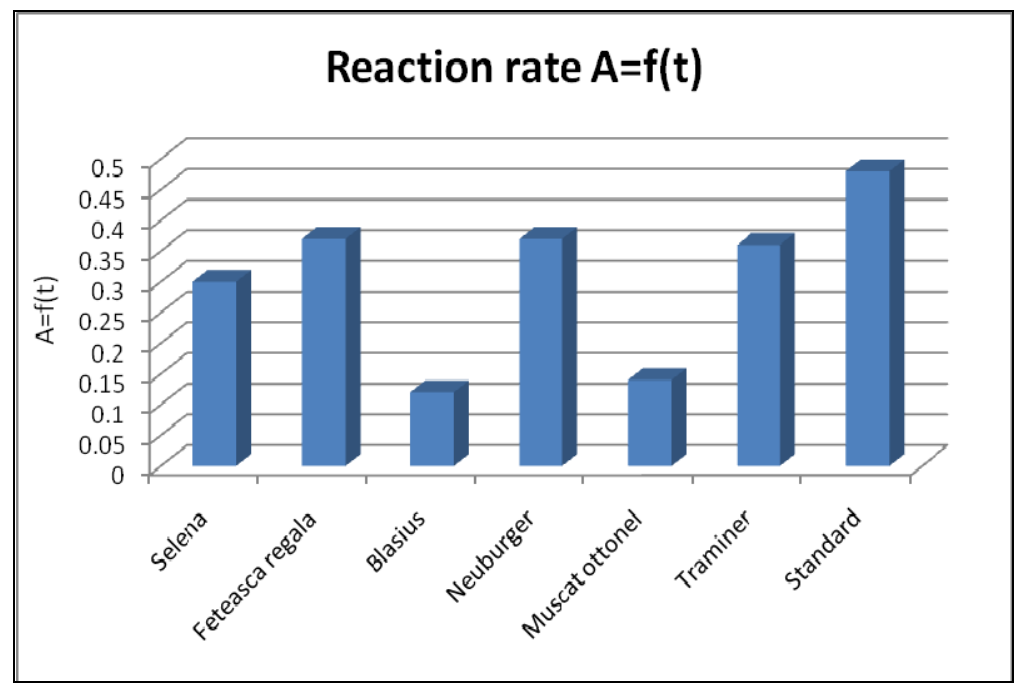

Figure 6. Comparation of reaction rates for tyrosinase enzyme inhibitory activity

\section{CONCLUSIONS}

The GC-MS method proved to be an excelent method for wine characterization. The volatile extracts of wines gave very similar compounds. The major compounds were phenylethyl alcohol. Amino acids are importance to wine flavour and aroma because they constitute a source for yeast metabolism. All the white wines of Blaj contained a large amounts of proline in comparison with the other amino acids and important essential amino acids. The fatty acids were found in very small quantities. Antioxidant activity and total content in polyphenols of wines showed that Muscat Ottonel have a very high antioxidant potential comparable with some red wines while the content in flavonoids is small in all white wines. Antityrosinasic activity of studied wine proved to be high for Blasius and Muscat Ottonel wine.

\section{EXPERIMENTAL SECTION}

\section{Material and methods}

White wines produced in year 2014 (Fetească regală, Blasius, Neuburger, Traminer, Muscat Ottonel, Selena) were procured from a vineyard from Blaj, Transylvania. All reactive and standards were purchased from Merck (Darmstadt, Germany). 
GC-MS apparatus A Trace DSQ Thermo Finnigan quadrupole mass spectrometer coupled with a Trace GC was used. The Rtx-5MS capillary column, $30 \mathrm{mx} 0.25 \mathrm{~mm}, 0.25 \mu \mathrm{m}$ film thickness was used in a temperature program from $50^{\circ} \mathrm{C}, 2 \mathrm{~min}$, then $8^{\circ} \mathrm{C} / \mathrm{min}$ to $250^{\circ} \mathrm{C}$, with $30^{\circ} \mathrm{C}$ $/ \mathrm{min}$ at $310^{\circ} \mathrm{C}(10 \mathrm{~min})$ for fatty acids and volatile compounds separation. The amino acids were separated by using another program: from $50^{\circ} \mathrm{C}, 1$ min, then increased with $6^{\circ} \mathrm{C} / \mathrm{min}$ to $100^{\circ} \mathrm{C}$, with $4^{\circ} \mathrm{C} / \mathrm{min}$ to $200^{\circ} \mathrm{C}$ and $20^{\circ} \mathrm{C} / \mathrm{min}$ to $300^{\circ}$ for $3 \mathrm{~min}$. The different extraction methods for volatile compounds, fatty acids and amino acids were described.

Extraction procedure for amino acids $100 \mathrm{ml}$ of wine and $50 \mu \mathrm{g}$ $\left[{ }^{15} \mathrm{~N}\right]$-glycine (internal standard) was passed through a Dowex $50 \mathrm{~W}$-W8 exchange resin, $4 \times 40 \mathrm{~mm}$ column (activated). The collected solution was dried in a nitrogen flow at $60^{\circ} \mathrm{C}$ or by using a vacuum centrifuge at $60^{\circ} \mathrm{C}$. The derivatization method included an esterification of the carboxylic function using $100 \mu \mathrm{l}$ butanol: acetyl chloride $(4: 1 \mathrm{v} / \mathrm{v})$, for $1 \mathrm{~h}$ at $110^{\circ} \mathrm{C}$, followed by an acetylation of the amine function using $100 \mu$ trifluoroacetic anhydride, for $20 \mathrm{~min}$ at $80^{\circ} \mathrm{C}$.

Extraction procedure for fatty acids $100 \mathrm{ml}$ of wine was sonicated with $0.6 \mathrm{ml}$ water $/ \mathrm{NaCl}$ and $0.8 \mathrm{ml}$ methanol for $1 \mathrm{~min}$, then mixed with 0.8 $\mathrm{ml}$ chloroform and $3 \mathrm{~min}$ centrifuged (5800 rot $/ \mathrm{min}$ ); the lower layer was collected and extraction was repeated with $0.4 \mathrm{ml}$ chloroform. The lower chloroform phase containing the extracted fatty acids was then dried in a nitrogen flow, at $60^{\circ} \mathrm{C}$.

The lipids were converted to corresponding fames (fatty acids methyl esters) by esterification of the carboxylic functions with $100 \mu \mathrm{L}$ methanol: acetyl chloride $4: 1$ ( v:v), $20 \mathrm{~min}, 80^{\circ} \mathrm{c}$. the derivatives were evaporated to dryness by a nitrogen stream, at $60^{\circ} \mathrm{C}$, and then dissolved in $500 \mu \mathrm{l}$ dichloromethane. $10 \mu \mathrm{g}$ of C11:1 was added to each sample for GC-MS quantitation.

Extraction procedure for volatiles $5 \mathrm{ml}$ wine was mixed $1 \mathrm{ml}$ with a solvent (mixture of ethyl acetate: hexane: dichloromethane, 5/1/1) for 2 min and centrifuged (5800 rpm) $3 \mathrm{~min}$. The supernatant was collected and $1 \mu \mathrm{l}$ was injected into the GC/MS.

\section{Determination of antioxidant activity}

DPPH antioxidant method For the determination of antioxidant activity, DPPH antioxidant assay was used. $10 \mu \mathrm{L}$ of each wine was used to decolorize an ethanolic solution of $40 \mu \mathrm{M}$ DPPH. The monitoring of DPPH 
reduction was followed at $517 \mathrm{~nm}$. The percentage of DPPH scavenging activity is expressed using following formula: $\mathrm{DPPH}_{\text {inhibition }} \%=\left[\left(A_{i}-A_{t}\right) / A_{i}\right] \times 100$.

Trolox equivalent antioxidant capacity assay (TEAC) For TEAC measurements a stock solution of ABTS $(10 \mathrm{mM})$ in sodium acetate buffer $(5 \mathrm{mM}, \mathrm{pH}=5)$ was activated with hydrogen peroxide $(7 \mu \mathrm{L}, 30 \%)$, and $5 \mu \mathrm{L}$ met hemoglobine for $1 \mathrm{~h}$. After activation, the obtained ABTS+• solution was centrifuged to separate the protein. In $748 \mu \mathrm{L}$ water, $2 \mu \mathrm{L}$ each wine sample was added and $50 \mu \mathrm{L}$ solution of ABTS+•. The absorbance was measured at $735 \mathrm{~nm}$. Samples were done in duplicates and converted in Trolox equivalents by using of a calibration curve $(R 2=0.9987)$ constructed with $0,2,4,6,8,10 \mathrm{mg} \cdot \mathrm{L}-1$ Trolox standards.

\section{Determination of polyphenols and flavonoid content}

Determination of polyphenolic content The total phenolic content (TPC) of wines was determined using the Folin-Ciocalteau method. Wines $(5 \mu \mathrm{L})$ was mixed with Folin-Ciocalteu reagent $(50 \mu \mathrm{L})$, distilled water $(795 \mu \mathrm{L})$ and $150 \mu \mathrm{L}$ solution of sodium carbonate (c=20\%). The samples were incubated in the dark for $30 \mathrm{~min}$. The absorbance was measured at $760 \mathrm{~nm}$. Experiments were done in duplicates. Gallic acid was used as standard for the calibration curve and was plotted at 2, 4, 6, 8, and $10 \mathrm{mg} \cdot \mathrm{L}-1$, prepared in ethanol. TPC values were determined using an equation obtained from the calibration curve of gallic acid graph (R2 $=0.9990)$. Results were expressed in $\mathrm{mg}$ of gallic $\mathrm{acid} / \mathrm{mL}$ of wine.

Determination of flavonoid content For determination of flavonoid content a spectrophotometric aluminum chloride method was used ${ }^{4}$. Wine sample $(200 \mu \mathrm{L})$ was mixed with sodium acetate $(200 \mu \mathrm{L}, 100 \mathrm{~g} \cdot \mathrm{L}-1)$, aluminium chloride $(120 \mu \mathrm{L}, 25 \mathrm{~g} \cdot \mathrm{L}-1$, and $480 \mu \mathrm{L}$ methanol. The absorbance was measured at $435 \mathrm{~nm}$. Total flavonoids content values were determined using an equation obtained from calibration curve of the quercitine graph (R2 = 0.991 ) obtained with $1,2,4,6,8$, and $10 \mu \mathrm{g} \cdot \mathrm{mL}-1$ quercitine in methanol. Results were expressed in $\mu \mathrm{g}$ of quercitine/mL of wine.

Determination of tyrosinase inhibition activity For determination of antyrosinasic activity of wines, a spectrophotometric method was used. To $897 \mu \mathrm{L}$ sodium phosphate buffer solution $(20 \mathrm{mM}, \mathrm{pH}=6.8), 4 \mu \mathrm{L}$ tyrosine water solution $(4 \mathrm{mM})$ and $3 \mu \mathrm{L}$ phosphate buffer solution of tyrosinase $(\geq 0.2 \mathrm{unit} / \mathrm{mg}$ solid in $1 \mathrm{uL}$ ) $20 \mu \mathrm{L}$ wine sample was added. The enzymatic reaction was followed at $475 \mathrm{~nm}$ for 15 minutes. The reaction rates were calculated from regression curve slope. 
R. BLEIZIFFER, S. SUVAR, P. PODEA, C. MESAROS, M. CULEA

REFERENCES

1. R.D. Boc, A. Dobrei, Journal of Horticulture, Forestry and Biotechnology, 2015, 19(2), 190.

2. T. Atkin, R. Johnson, International Journal of Wine Business Research, 2010, 22(1), 42.

3. http://www.crameromania.ro/en//en/wineries/jidvei-winery-mysterium-188.html

4. S.H. Eom, W.J. Cheng, J.P. Hyoung, E.H. Kim, M.I. Chung, M.J. Kim, C.Y. Yu, D.H. Cho, Korean Journal of Medicinal Crop Science, 2007, 15, 319.

5. Y. Bouzas-Cid, E. Falqué, I. Orriols, E. Trigo-Córdoba, E. Díaz-Losada, D. Fornos-Rivas , J.M. Mirás-Avalos, Ciência e Técnica Vitivinícola, 2015, 30(2), 84

6. E. Soto Vazquez, S. Rıo Segade, S. Cortes Dieguez, International Journal of Food Science and Technology, 2011, 46(3), 542.

7. E. Bouloumpasi, E. H. Soufleros, C. Tsarchopoulos,C. G. Biliaderis, Vitis, 2002, 41(4), 195.

8. L. Jaitz, K. Siegl, R. Eder et al., Food Chemistry, 2010, 122(1), 366.

9. P. Hernandez-Orte, M. J. Ibarz, J. Cacho, V. Ferreira, Chromatographia 2003, 58, 29.

10. Purificación Hernández-Orte, Juan F. Cacho, and Vicente Ferreira, Journal of Agricultural Food Chemistry, 2002, 50 (10), 2891.

11. V. Avram, C G. Floare, A Hosu, C. Cimpoiu, C. Măruţoiuc, Z. Moldovan, Analytical Letters, 2015, 481099.

12. S. Y. Shu, J.G. Wen, Z. Yu Ping, Food Chemistry, 2011, 127, 547.

13. K. W. Lee, H. J. Hur, H. J. Lee, C. Y. Lee, Journal of Agricultural and Food Chemistry, 2005, 53, 1990.

14. K. M. Yoo, M. Al-Farsi, H. Lee, H. Yoon, C. Y. Lee, Food Chemistry, 2010, 123, 734.

15. http://www.scvblaj.ro/scdvv-blaj-en/

16. B. Zoecklin, K. Fugelsang, B. Gump, F. Nury, „Wine Analysis and Production” Chapman \& Hall New York, 1995.

17. M. Seruga, I. Novak, L. Jakobek, Food Chemistry, 2011, 124, 1208.

18. A. Hosu, V. M.Cristea, C. Cimpoiu, Food Chemistry, 2014, 150, 113.

19. I. Garaguso, M. Nardini, Food Chemistry, 2015, 179, 336.

20. A. Hosu, V. Floare-Avram, D. A.Magdas, I. Feher, M. Inceu, C. Cimpoiu, Journal of Analytical Methods in Chemistry, 2016, 4, 1-10.

21. D. Komes, D. Ulrich, K. Kovacevic Ganic, T. Lovric, Vitis, 2007, 46(2), 77.

22. S.Y Seo, V. K. Sharma, N.Sharma, Journal of Agricultural Food Chemistry 2003, 51, 2837.

23. M. R. Loizzo, R. Tundis, F. Menichini, Comprehensive Reviews in Food Science and Food Safety, 2012, 11, 378. 